\title{
Kesulitan Siswa SMP dalam Menyelesaikan Soal Cerita Sistem Persamaan Linear Dua Variabel
}

\author{
Widi Pradini ${ }^{1}$, Gatot Muhsetyo ${ }^{1}$, Swasono Rahardjo ${ }^{1}$ \\ ${ }^{1}$ Pendidikan Matematika-Universitas Negeri Malang
}

\begin{tabular}{l} 
INFO ARTIKEL \\
\hline Riwayat Artikel: \\
Diterima: $24-06-2019$ \\
Disetujui: $15-01-2020$ \\
\hline
\end{tabular}

Kata kunci:

word problem;

system of linear equation in two variables;

soal cerita;

sistem persamaan linear dua variabel

\begin{abstract}
Mathematical word problem is one of the difficult problems to solve. The purpose of this research is to describe the difficulties of SMP Negeri 1 Karanngejo students when solving word problem about system of linear equation in two variables. Data collection is done by using test and direct interview to 3 research subjects. Data is analyzed qualitatively through data reduction, data presentation, and drawing conclusion. The result of the research show that student difficulties lie on the devise a plan step, those are difficulty to transform relevant information into variable and difficulty to construct linear equation in two variables that represents the relation between relevant information in the word problem.
\end{abstract}

ABSTRAK

\begin{abstract}
Abstrak: Soal cerita matematika merupakan salah satu soal yang sulit diselesaikan oleh siswa. Tujuan dari penelitian ini adalah untuk mendeskripsikan kesulitan siswa SMP Negeri 1 Karangrejo saat menyelesaikan soal cerita matematika tentang materi sistem persamaan linear dua variabel. Pengumpulan data dilakukan dengan tes dan wawancara langsung terhadap tiga subjek penelitian. Data dianalisis secara kualitatif melalui tahap reduksi data, penyajian data, dan pengambilan kesimpulan. Hasil penelitian menunjukkan bahwa kesulitan dialami siswa pada tahap merencanakan penyelesaian masalah, yaitu kesulitan dalam mengubah informasi relevan ke dalam variabel dan kesulitan dalam menyusun persamaan linear dua variabel yang menunjukkan hubungan antar informasi relevan dalam soal cerita.
\end{abstract}

\section{Alamat Korespondensi:}

Widi Pradini

Pendidikan Matematika

Universitas Negeri Malang

Jalan Semarang 5 Malang

E-mail: pradiniwidi@gmail.com

Soal cerita matematika merupakan soal dengan karakteristik tersendiri dan berbeda dengan soal matematika pada umumnya. Karakteristik dari soal cerita matematika yang paling jelas adalah informasi-informasi relevan dalam soal disajikan dalam bentuk teks atau kalimat-kalimat, tidak hanya dalam bentuk notasi matematika (Boonen, de Koning, Jolles, \& van der Schoot, 2016). Selain penyajian informasinya, masalah yang digambarkan dalam soal cerita matematika juga berhubungan dengan suatu konteks dunia nyata (Verschaffel, Greer, Mukhopadhyay, \& Van Dooren, 2009). Konteks dunia nyata yang digambarkan, menghendaki siswa untuk membaca dan memahami soal cerita dengan cermat, sehingga siswa dapat menyelesaikan soal cerita dengan pemahaman materi matematika yang siswa miliki (Fatmanissa \& Kusnandi, 2017). Jadi, dalam menyelesaikan soal cerita, siswa perlu memahami teks yang disajikan untuk mengidentifikasi informasi yang relevan, memunculkan suatu rencana untuk menyelesaikannya, dan menampilkan kalkulasi untuk menentukan solusi yang tepat (Sahendra, Budiarto, \& Fuad, 2018).

Soal cerita adalah soal yang dapat digunakan untuk mengetahui kemampuan siswa dalam melakukan kegiatan pemecahan masalah. Dalam melakukan kegiatan pemecahan masalah, siswa akan melalui beberapa tahap penyelesaian. Menurut Polya (dalam Yuan, 2013), siswa akan menyelesaikan masalah melalui empat tahap pemecahan masalah, yaitu (1) memahami masalah atau understand the problem, (2) merencanakan penyelesaian masalah atau devise a plan, (3) melaksanakan rencana penyelesaian masalah atau carry out the plan, dan (4) memeriksa kembali atau looking back. Yuan (2013) menyatakan bahwa dalam memahami masalah siswa harus tahu informasi apa yang diketahui dan ditanyakan sehingga siswa dapat merencanakan bagaimana cara menentukan hubungan antar informasi yang diketahui untuk menjawab informasi yang ditanyakan dalam tahap merencanakan penyelesaian masalah. Dalam tahap melaksanakan rencana penyelesaian siswa menampilkan langkah-langkah penyelesaian dan tahap memeriksa kembali, meliputi kegiatan siswa dalam memastikan bahwa masalah sudah terjawab dengan benar (Yuan, 2013). Agar siswa dapat berhasil dalam melalui tahap pemecahan masalah dengan soal cerita, siswa membutuhkan pengetahuan, keterampilan dan kemampuan kognitif yang cukup. 
Salah satu keterampilan yang diperlukan adalah keterampilan pemahaman bacaan. Keterampilan pemahaman bacaan memungkinkan siswa untuk memahami masalah sehingga siswa dapat mengidentifikasi informasi relevan yang dapat digunakan untuk menyelesaikan masalah (Boonen et al., 2016). Selain keterampilan bahasa, siswa juga perlu memiliki pengetahuan tentang ilmu bahasa, pengetahuan representasi skema, pengetahuan algoritma, dan keseluruhan keterampilan komputasi (Kingsdorf \& Krawec, 2014). Pada kenyataannya, soal cerita matematika merupakan soal yang sulit dikerjakan bagi siswa. Siswa merasa kesulitan karena soal cerita matematika memang memberikan siswa tantangan untuk menerapkan pemikiran matematikanya dalam berbagai situasi (Sahendra et al., 2018). Seperti yang telah dibahas sebelumnya pula, soal cerita dapat digunakan untuk mengetahui kemampuan pemecahan masalah matematika siswa, dan belajar bagaimana memecahkan masalah matematika telah lama menjadi kesulitan yang dialami siswa (Ahmad, Tarmizi, \& Nawawi, 2010). Daroczy, Wolska, Meurers, \& Nuerk (2015) pun menambahkan bahwa soal cerita matematika termasuk ke dalam tipe soal yang paling sulit dan rumit yang dialami siswa selama perkembangan matematika di tingkat dasar.

Ada berbagai bentuk kesulitan yang dialami siswa saat menyelesaikan soal cerita. Bentuk kesulitan yang dialami siswa yang pertama adalah dalam membaca soal cerita. Siswa yang kesulitan membaca soal cerita tidak dapat memahami soal dengan baik karena ada kata-kata yang tidak dimengerti dalam soal (Sepeng \& Sigola, 2013). Kesulitan yang dialami siswa selanjutnya adalah dalam mengidentifikasi informasi relevan yang dapat digunakan untuk menyelesaikan soal cerita (Kingsdorf \& Krawec, 2014). Selain kesulitan dalam membaca dan mengidentifikasi informasi relevan, kesulitan yang dialami siswa adalah dalam mengubah informasi dalam kalimat biasa ke dalam variable atau membentuk model matematika (Jupri \& Drijvers, 2016). Oleh karena siswa tidak dapat membentuk model matematika, siswa pun juga mengalami kesulitan dalam menampilkan langkah penyelesaian (Jupri \& Drijvers, 2016). Sistem persamaan linear dua variabel adalah salah satu materi matematika yang wajib dipelajari siswa di SMP. Sistem persamaan yang diajarkan di SMP memuat dua persamaan linear dua variabel. Bentuk umum sistem persamaan linear dengan dua variabel $x$ dan $y$ adalah dengan syarat $a_{1}$ dan $b_{1}$ tidak keduanya nol, $a_{2}$ dan $b_{2}$ tidak keduanya nol, serta $a_{1}, b_{1}, c_{1}, a_{2}, b_{2}$, dan $c_{2}$ adalah anggota bilangan riil(Anton \& Rorres, 2005).

$$
\left\{\begin{array}{l}
a_{1} x+b_{1} y=c_{1} \\
a_{2} x+b_{2} y=c_{2}
\end{array}\right.
$$

Solusi dari sistem persamaan linear dua variabel adalah pasangan berurutan bilangan riil $(x, y)$ yang memenuhi setiap persamaan dalam sistem(Larson \& Hostetler, 2008). Untuk memperoleh solusi dari sistem persamaan linear dua variabel di SMP, siswa dapat menggunakan metode grafik, substitusi, eliminasi, atau campuran antara substitusi dan eliminasi. Berdasarkan grafiknya, ada tiga kemungkinan solusi dari sistem persamaan linear dua variabel. Misalkan garis $l_{1}$ adalah grafik persamaan $a_{1} x+b_{1} y=c_{1}$ dan garis $l_{2}$ adalah grafik persamaan $a_{2} x+b_{2} y=c_{2}$ dalam sistem (1). Tiga kemungkinan grafik dari sistem persamaan linear dua variabel dapat dilihat pada Gambar 1. Tiga kemungkinan solusi dari sistem persamaan linear dua variabel dilihat dari grafiknya adalah dua garis sejajar menandakan bahwa sistem memiliki solusi, dua garis berpotongan menandakan bahwa sistem memiliki satu solusi dan dua garis berhimpit menandakan bahwa sistem memiliki tak hingga solusi (Anton \& Rorres, 2005).

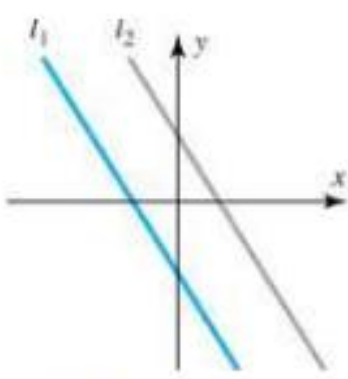

(a) Dua Garis Sejajar

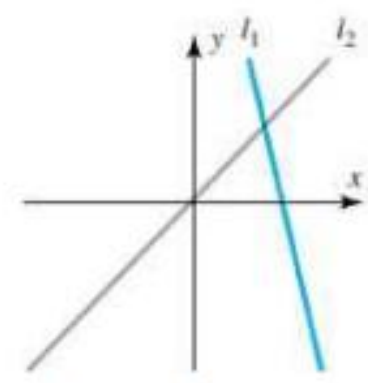

(b) Dua Garis Berpotongan

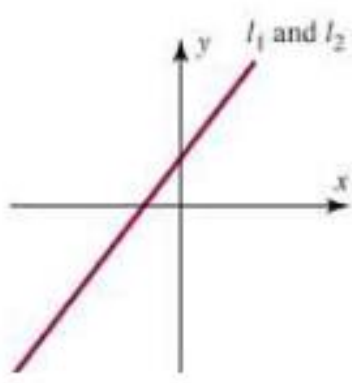

(c) Dua Garis Berhimpit

\section{Gambar 1. Tiga Kemungkinan Grafik Sistem Persamaan Linear Dua Variabel}

Untuk menyelesaikan soal cerita matematika tentang persamaan linear dua variabel, sebelum siswa dapat menerapkan metode penyelesaian, siswa perlu membuat model matematika dari masalah yang disajikan dalam soal cerita. Berdasarkan wawancara dengan guru matematika SMP Negeri 1 Karangrejo, penelitian yang terkait dengan kesulitan siswa dalam mengerjakan soal cerita belum pernah dilakukan, terlebih lagi untuk soal cerita yang berkaitan dengan sistem persamaan linear dua variabel. Peneliti memandang perlu diadakannya penelitian mengenai kesulitan siswa dalam mengerjakan soal cerita tentang sistem persamaan linear dua variabel di SMP Negeri 1 Karangrejo. 


\section{METODE}

Penelitian ini merupakan penelitian kualitatif deskriptif karena peneliti akan mendeskripsikan kesulitan siswa dalam mengerjakan soal cerita sesuai dengan fakta yang ada di lapangan. Lokasi penelitian ada di SMP Negeri 1 Karangrejo, Kec. Karangrejo, Kab. Magetan. Penelitian dilakukan kepada 24 siswa kelas VIII G pada semester gasal tahun ajaran 2018/2019. Proses pengumpulan data kesulitan melalui tes berupa soal cerita sistem persamaan linear dua variabel dan wawancara. Analisis data kesulitan siswa melalui beberapa tahap diantaranya adalah (1) reduksi data, (2) penyajian data, dan (3) pengambilan kesimpulan (Miles \& Hubermann, 1992). Soal cerita yang disusun peneliti dapat dilihat pada tabel 1.

\section{Tabel 1. Instrumen Penelitian}

\begin{tabular}{l} 
Soal Cerita Persamaan Linear Dua Variabel \\
Masalah: \\
Saat ini umur Ahsan sama dengan empat kali umur Nia. Lima tahun lalu, umur Ahsan sama dengan sembilan kali umur Nia \\
\hline Pertanyaan: \\
a. Berapa banyak orang yang ada dalam soal? \\
b. Apa yang dibahas dalam soal? \\
c. Jika saat ini umur Ahsan dinyatakan dengan $x$, maka bagaimana hubungan antara umur Nia dan umur Ahsan saat ini? \\
d. Jika saat ini umur Ahsan dinyatakan dengan $x$, maka bagaimana hubungan antara umur Ahsan dan umur Nia lima tahun lalu? \\
e. Berapa tahun lagi agar umur Ahsan sama dengan tiga kali umur Nia? Tuliskan alasanmu.
\end{tabular}

Langkah pertama dalam mengumpulkan data kesulitan siswa adalah pemberian soal tes kepada seluruh siswa. Siswa mengerjakan tes selama 40 menit atau satu jam pelajaran. Langkah kedua setelah mendapatkan data tertulis siswa, peneliti mengidentifikasi kesulitan siswa dalam menyelesaikan soal cerita berdasarkan indikator kesulitan pada tabel 2 . Dari hasil identifikasi tersebut, peneliti memilih beberapa siswa berdasarkan banyaknya indikator kesulitan yang sudah terhitung. Peneliti juga mempertimbangkan rekomendasi guru berkaitan dengan siswa yang memiliki kemampuan matematika tinggi, sedang, dan rendah sehingga peneliti memperoleh tiga subjek penelitian. Langkah ketiga setelah peneliti menentukan subjek penelitian, peneliti melakukan wawancara untuk menggali informasi lebih dalam dari jawaban tertulis subjek.

\section{Tabel 2. Indikator Kesulitan Siswa}

\begin{tabular}{|c|c|}
\hline Tahap Pemecahan Masalah Polya & Indikator Kesulitan \\
\hline \multirow[t]{2}{*}{ Memahami masalah } & 1. Siswa salah atau tidak menuliskan berapa banyak orang dalam masalah \\
\hline & 2. Siswa salah atau tidak menuliskan topik yang dibahas dalam masalah \\
\hline \multirow[t]{3}{*}{ Merencanakan penyelesaian masalah } & 3. Siswa tidak memunculkan variabel yang mewakili umur Nia saat ini \\
\hline & $\begin{array}{l}\text { 4. Siswa salah atau tidak menuliskan persamaan linear dua variabel yang menunjukkan } \\
\text { hubungan antara umur Ahsan saat ini }\end{array}$ \\
\hline & $\begin{array}{l}\text { 5. Siswa salah atau tidak menuliskan persamaan linear dua variabel yang menunjukkan } \\
\text { hubungan antara umur Ahsan dan umur Nia lima tahun lalu }\end{array}$ \\
\hline \multirow[t]{3}{*}{ Melaksanakan rencana penyelesaian } & $\begin{array}{l}\text { 6. Siswa tidak menggunakan metode substitusi, eliminasi atau campuran antara substitusi } \\
\text { dan eliminasi dalam mencari umur Ahsan dan umur Nia saat ini }\end{array}$ \\
\hline & 7. Siswa hanya mengoperasikan bilangan-bilangan yang tertera dalam soal \\
\hline & $\begin{array}{l}\text { 8. Siswa salah atau tidak menuliskan berapa tahun lagi agar umur Ahsan sama dengan tiga } \\
\text { kali umur Nia }\end{array}$ \\
\hline
\end{tabular}

\section{HASIL}

Hasil penelitian menunjukkan bahwa seluruh siswa yang mengikuti tes mengalami kesulitan saat menyelesaikan soal cerita. Kesulitan utama yang dialami siswa terletak pada tahap merencanakan penyelesaian masalah. Kesulitan dalam merencanakan penyelesaian masalah diidentifikasi dari indikator 3-5 Tabel 2 yang menyatakan bahwa siswa tidak memunculkan variabel yang mewakili informasi relevan dalam soal dan siswa salah atau tidak menuliskan persamaan linear yang menunjukkan hubungan antara informasi relevan dalam soal cerita. Penjelasan lebih lanjut mengenai kesulitan yang dialami siswa ada dalam paragraf berikutnya.

Kesulitan siswa dalam tahap merencanakan penyelesaian dapat diketahui dari kesalahan atau ketidasesuaian jawaban siswa dalam menjawab pertanyaan (c) dan (d). Pertanyaan (c) mendorong siswa memunculkan variabel yang mewakili umur Nia dan membentuk persamaan linear yang menunjukkan hubungan antara umur Ahsan dan umur Nia saat ini. Pertanyaan (d) mirip dengan pertanyaan (c), hanya saja persamaan linear yang diinginkan adalah tentang hubungan antara umur Ahsan dan umur Nia lima tahun lalu. Berdasarkan hasil tes, terdapat 19 siswa yang tidak memunculkan variabel yang mewakili umur Nia, 20 siswa salah atau tidak menuliskan persamaan linear yang menunjukkan hubungan antara umur Ahsan dan umur Nia saat ini dan 24 siswa salah atau tidak menuliskan persamaan linear dua variabel yang menunjukkan hubungan antara umur Ahsan dan umur Nia lima tahun lalu. 


\section{c. Jika saat ini umur Ahsan dinyatakan dengan $x$, maka bagaimana hubungan antara umur Nia dan umur Ahsan saat ini?}

$x=y \quad x=$ umur $4 x$ dari umur Nia don Hia addalh Solisih $4 x$,
$x=$ umur Ahsan. Umur nia Jadi,

\section{Gambar 2. Jawaban (c) Subjek 1}

Dalam menjawab pertanyaan (c), subjek 1 sudah memunculkan variabel $y$, tetapi tidak ada keterangan yang menunjukkan bahwa variabel $y$ yang dituliskan mewakili umur Nia. Subjek 1 malah menyamadengankan variabel $x$ dengan variabel $y$. Subjek belum menyusun persamaan linear yang diminta dan menjawab bahwa hubungan antara umur Ahsan dan umur Nia adalah selisih 4. Subjek 1 tampak kebingungan dalam menjawab pertanyaan (c) karena subjek menuliskan beberapa jawaban yang saling tidak berhubungan. Sebenarnya, subjek 1 sudah membuat model verbal yang sesuai dan sudah memunculkan variabel lain, tetapi subjek tidak menggunakan variabel tersebut untuk mewakili umur Nia. Contoh jawaban pertanyaan (c), dapat dilihat pada gambar 2.

\section{d. Jika saat ini umur Ahsan dinyatakan dengan $x$, maka bagaimana hubungan antara umur Ahsan dan umur Nia lima tahun lalu?

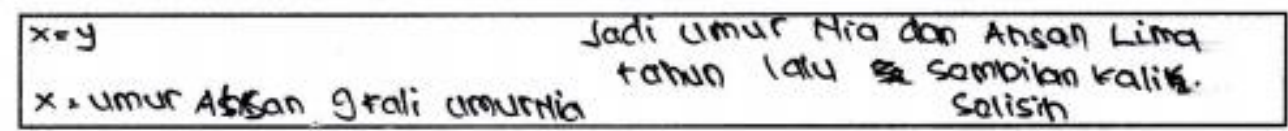

Gambar 3. Jawaban (d) Subjek 1

Secara umum, jawaban pertanyaan (d) subjek 1 hampir mirip dengan jawaban pertanyaan (c). Untuk jawaban pertanyaan (d), subjek 1 juga memunculkan variabel $y$ tanpa keterangan dan menyamadengankan variabel $y$ dengan variabel $x$. Subjek juga tidak menyusun persamaan linear dan menjawab bahwa umur Ahsan dan umur Nia adalah selisih sembilan kali. Walaupun subjek 1 sudah memunculkan variabel baru $y$, tetapi tidak mengganti umur Nia dengan variabel $y$, tidak dapat melanjutkan langkah penyusunan persamaan linearnya. Subjek menyebutkan kata "selisih" lagi saat menjawab pertanyaan (d). Contoh jawaban pertanyaan (d) subjek 1 dapat dilihat pada gambar 3.

\section{c. Jika saat ini umur Ahsan dinyatakan dengan $x$, maka bagaimana hubungan antara umur Nia dan umur Ahsen saat ini?$$
x(\text { Ahsan })=x(\text { Ahsan })+4 x(N \text { la })
$$

\section{Gambar 4. Jawaban (c) Subjek 2}

Dalam menjawab pertanyaan (c) subjek 2 belum memunculkan variabel yang mewakili umur Nia dan hanya menggunakan satu variabel untuk mewakili umur Ahsan dan umur Nia. Subjek 2 langsung menyusun persamaan linear yang diminta dalam soal. Persamaan linear yang disusun siswa hanya memuat satu variabel dan siswa menuliskan nama Ahsan dan Nia di belakang variabel. Dari jawaban subjek tersebut, sudah jelas bahwa subjek belum bisa mengubah informasi yang relevan ke dalam variabel. Selain pengubahan informasi relevan ke dalam variabel, siswa juga belum paham bagaimana cara menyusun persamaan linear dua variabel dengan benar. Akibatnya, subjek salah dalam menentukan persamaan linear yang diminta dalam pertanyaan (c). Contoh jawaban pertanyaan (c) subjek 2, dapat dilihat pada gambar 4.

\section{d. Jika saat ini umur Ahsan dinyatakan dengan $x$, maka bagaimana hubungan antara umur} Ahsan dan umur Nia lima tahun lalu?

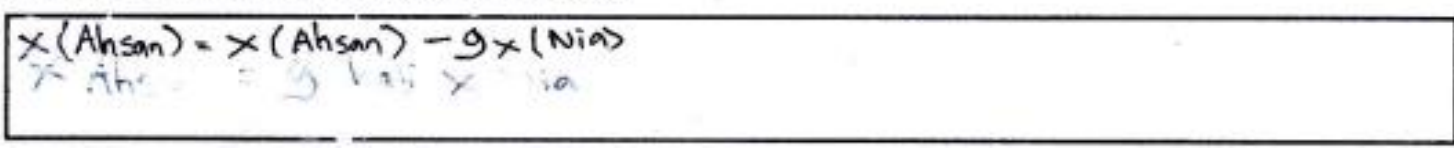

Gambar 5. Jawaban (d) Subjek 2 
Penulisan nama di belakang variabel bertujuan sebagai pembeda variabel $x$ mana yang mewakili umur Ahsan dan varibel $x$ mana yang mewakili umur Nia. Dari hasil wawancara pun subjek menjawab bahwa nama yang ada dalam kurung adalah $x$. Dari hasil wawancara dengan subjek 2, subjek mengaku belum memahami bagaimana membuat permisalan dalam sistem persamaan linear dua variabel. Cuplikan hasil wawancara peneliti dengan subjek 2 sebagai berikut:

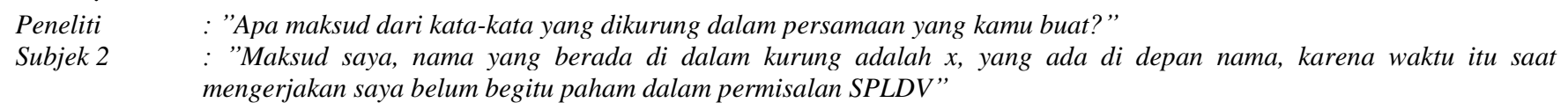

Sama halnya dengan subjek 1, jawaban pertanyaan (d) subjek 2 juga mirip dengan jawaban pertanyaan (c). Perbedaan jawaban terletak pada bilangan yang menjadi koefisien dari $x$. Apabila di jawaban pertanyaan (c) subjek 1 menuliskan $4 x$, di jawaban pertanyaan (d) subjek 2 menuliskan 9x. Perbedaan bilangan yang dituliskan tersebut terkait dengan informasi umur Ahsan dan umur Nia yang ada dalam soal cerita. Selain koefisien $x$, perbedaan lain dari persamaan yang disusun subjek 2 adalah operasi yang digunakan. Apabila dalam pertanyaan (c) subjek 2 menggunakan operasi penjumlahan, dalam jawaban pertanyaan (d) subjek 2 menggunakan operasi pengurangan. Contoh jawaban pertanyaan (d) subjek 2, dapat dilihat pada gambar 5.

\section{c. Jika saat ini umur Ahsan dinyatakan dengan $x$, maka bagaimana hubungan antara umur Nia dan umur Ahsan saat ini?}

Hub tersebur adalah
$Y$ calah $\mathrm{Ma} . \times 4-5=-1$

\section{Gambar 6. Jawaban (c) Subjek 3}

Dalam menjawab pertanyaan (c), subjek 3 sudah memunculkan variabel y yang mewakili umur Nia. Akan tetapi, Subjek 3 salah dalam menyusun persamaan linear yang diminta pertanyaan (c). Persamaan linear yang disusun subjek 3 malah tidak memuat variabel $y$. Subjek 3 juga menuliskan bilangan 5 dalam persamaan linear yang sudah dibuat, yang mana bilangan 5 tidak ada dalam suku-suku persamaan linear dua variabel yang menunjukkan hubungan antara umur Ahsan dan umur Nia, yaitu $x=4 y$. Bilangan 5 dalam soal cerita berkaitan dengan informasi umur Ahsan dan umur Nia lima tahun lalu dan merupakan informasi yang tidak relevan untuk menjawab pertanyaan (c). Jawaban pertanyaan (c) subjek 3 dapat dilihat pada gambar 6.

\section{d. Jika saat ini umur Ahsan dinyatakan dengan $x$, maka bagaimana hubungan antara umur Ahsan dan umur Nia lima tahun lalu?}

Hub tersebut adabh $\times$ odalaluh Semitian kali dari $y, y$ adalah
Nia $\times 9-4=5$

\section{Gambar 7. Jawaban (d) Subjek 3}

Jawaban pertanyaan (d) subjek 3 mirip dengan jawaban pertanyaan. Akan tetapi, persamaan linear yang disusun subjek tiga hanya memuat variabel $y$. Subjek 3 sudah menyebutkan bahwa " $x$ adalah sembilan kali dari $y$ ", tetapi belum bisa menyusun persamaan dengan benar. Pada ruas kanan persamaan yang disusun subjek, terdapat bilangan 5 yang merupakan hasil dari 9 dikurangi 4. Padahal sebenarnya 9 merupakan satu bagian dengan $y$ dan tidak dapat dioperasikan dengan 4 . Dalam menjawab pertanyaan (c) pun subjek juga mengurangkan 4 dengan 5 sehingga memperoleh hasil -1 di ruas kanan persamaan yang disusun. Jawaban pertanyaan (d) subjek dapat dilihat pada gambar 7.

Dari jawaban subjek tersebut, tampak bahwa subjek belum bisa menyusun persamaan linear dengan benar walaupun subjek sudah bisa mengubah informasi tentang umur Nia ke dalam variabel y. Ketika ditanya tentang persamaan yang subjek susun, jawaban subjek berubah-ubah. Oleh karena jawaban subjek yang berubah-ubah tersebut, peneliti menganggap bahwa Subjek 3 tidak paham apa maksud persamaan yang sudah disusun. Subjek pun mengaku bingung dalam menjawab pertanyaan (c) dan pertanyaan (d). Cuplikan wawancara antara subjek 3 dengan peneliti mengenai jawaban subjek adalah sebagai berikut.

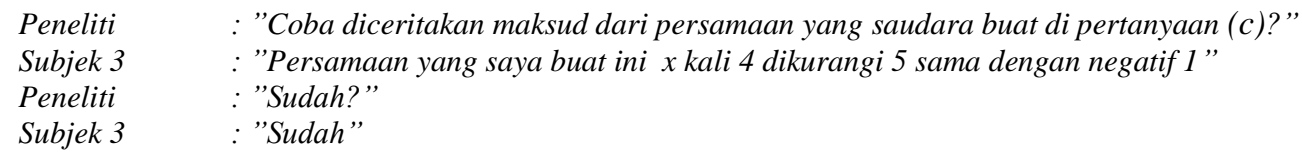




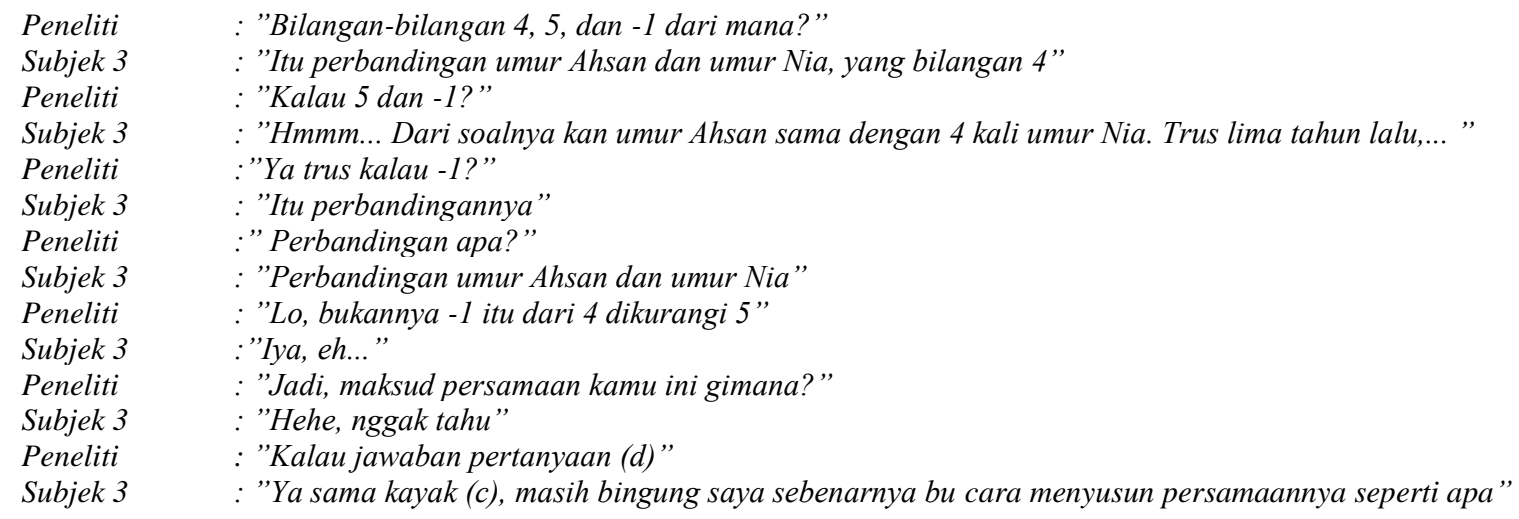

Subjek 3 walaupun sudah memunculkan variabel baru yang mewakili umur Nia, tidak menyusun persamaan linear yang terdiri dari dua variabel. Subjek 3 menyusun persamaan linear yang memuat variabel $x$ untuk hubungan umur Ahsan dan Nia saat ini dan menyusun persamaan linear yang memuat variabel $y$ untuk hubungan umur lima tahun lalu. Kesalahan dalam penyusunan persamaan linear dua variabel subjek 3 disebabkan karena subjek salah dalam mengidentifikasi informasi yang relevan untuk menjawab pertanyaan. Subjek juga tidak dapat mengubah dan memadukan istilah "lima tahun lalu" ke dalam persamaan yang subjek susun.

Dalam menjawab pertanyaan (e), ketiga subjek hanya mengoperasikan bilangan yang tertera dalam soal. Contoh jawaban subjek yang hanya mengoperasikan bilangan dapat dilihat pada gambar 8. Seharusnya untuk menjawab pertanyaan (e), siswa menentukan berapa umur Ahsan dan umur Nia saat ini. Untuk menentukan umur Ahsan dan umur Nia, siswa perlu menyelesaikan persamaan-persamaan yang sudah dibentuk di pertanyaan (c) dan (d) menggunakan metode substitusi, eliminasi, atau campuran. Oleh karena siswa belum dapat menyusun persamaan linear dua variabel, siswa juga tidak dapat memperoleh jawaban yang benar di pertanyaan (e).

\section{e. Berapa tahun lagi agar umur Ahsan sama dengan tiga kali umur Nia? Tuliskan alasanmu.}

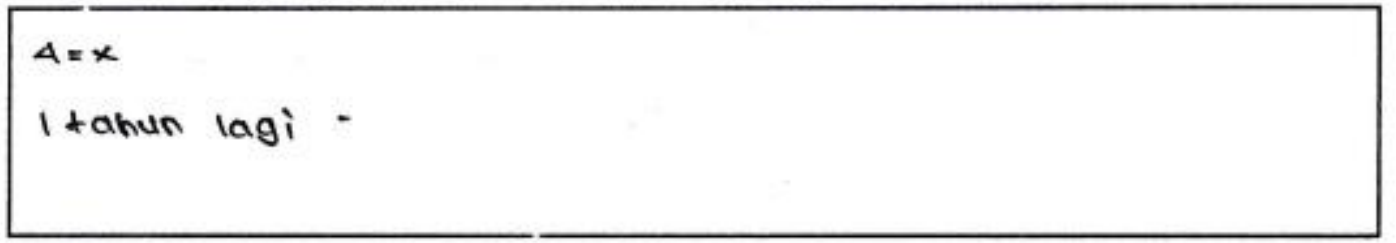

Gambar 8. Jawaban (e) Subjek 1

\section{PEMBAHASAN}

Berdasarkan hasil penelitian, kesulitan yang paling banyak yang dialami siswa ada dalam tahap merencanakan penyelesaian masalah. Kesulitan siswa dalam tahap merencanakan penyelesaian masalah adalah kesulitan dalam mengubah informasi relevan ke dalam variabel dan menyusun persamaan linear dua variabel yang menunjukkan hubungan antar informasi relevan. Berdasarkan hasil penelitian, siswa belum mengerti bagaimana membuat permisalah dalam sistem persamaan linear dua variabel dan menyusun persamaan linear yang tepat yang menunjukkan hubungan antara umur Ahsan dan umur Nia. Dengan kata lain, siswa mengalami kesulitan dalam membuat representasi atau model matematika dari informasi relevan yang tersaji dalam soal cerita. Temuan ini sejalan dengan hasil penelitian Jupri \& Drijvers (2016) yang menyatakan bahwa siswa mengalami kesulitan dalam membuat model matematika saat menyelesaikan soal cerita. Ahmad et al. (2010) juga menyatakan bahwa kesulitan siswa dalam menyelesaikan soal cerita dimulai dari menerjemahkan kalimat biasa ke dalam representasi matematika.

Representasi matematika menghendaki siswa untuk menemukan dan mengembangkan suatu alat dalam mengomunikasikan ide-ide matematika dari abstrak ke konkrit (Sahendra et al., 2018). Oleh karena siswa tidak dapat membuat representasi matematika yang tepat, siswa pun mengalami kesulitan dalam menyelesaikan soal cerita sistem persamaan linear dua variabel yang disusun peneliti. Hal ini didukung oleh hasil penelitian Sajadi, Amiripour, \& Rostamy-malkhalifeh (2013) yang menyatakan bahwa siswa yang memiliki kesulitan dalam merepresentasikan masalah matematika akan mengalami kesulitan dalam menyelesaikan masalah tersebut. Sajadi et al. (2013) menambahkan bahwa representasi masalah yang tepat menunjukkan bahwa pemecah masalah telah memahami masalah secara mendalam dan representasi masalah tersebut dapat memandu siswa menuju ke rencana penyelesaian yang sesuai. Berdasarkan pendapat Sajadi et al. (2013), dilihat dari bagaimana siswa membuat representasi dari informasi relevan dalam soal cerita, tampak bahwa siswa juga kesulitan dalam memahami masalah. 
Temuan mengenai kesulitan dalam memahami masalah ini didukung oleh hasil penelitian Sepeng \& Sigola (2013)yang menyatakan kesulitan yang dialami siswa saat menyelesaikan soal cerita adalah dalam membaca dan memahami (making sense) soal cerita matematika. Penyebab kesulitan dalam membaca dan memahami masalah, yaitu (1) siswa tidak memahami kata-kata yang diketahui dalam soal; (2) susunan kata yang digunakan dalam kalimat soal cerita; (3) banyaknya kata yang digunakan dalam soal cerita (Sepeng \& Sigola, 2013). Berdasarkan hasil jawaban siswa dalam penelitian ini, kesulitan dalam memahami masalah yang dialami siswa disebabkan oleh susunan kata yang digunakan dalam kalimat soal cerita.

Selain kesulitan dalam memahami masalah, penyebab siswa mengalami kesulitan dalam membuat representasi atau model matematika adalah karena keterampilan representasi siswa yang kurang. Menurut Boonen et al. (2016) keterampilan representasi memungkinkan siswa untuk membuat rencana penyelesaian dan menggunakan operasi matematika yang sesuai untuk menyelesaikan soal cerita. Oleh karena keterampilan representasi siswa masih belum cukup, siswa juga tidak dapat menentukan rencana penyelesaian yang sesuai dan gagal dalam menggunakan operasi matematika yang benar. Boonen et al. (2016) menambahkan bahwa keterampilan representasi memiliki keterkaitan yang erat dengan keterampilan pemahaman bacaan yang memungkinkan siswa untuk mengidentifikasi informasi relevan dalam soal cerita.

Kesulitan lain yang ditemukan dalam penelitian ini adalah kesulitan mengidentifikasi informasi relevan dalam soal cerita. Kesulitan ini diketahui dari kesalahan siswa dalam menyusun persamaan linear menggunakan informasi yang tidak relevan. Temuan ini berkaitan dengan hasil penelitian Kingsdorf \& Krawec (2014) yang menyatakan bahwa kesalahan utama dalam menyelesaikan soal cerita yang dialami siswa dengan kesulitan belajar dan siswa dengan kemampuan rata-rata adalah menentukan informasi relevan terkait dengan pemilihan bilangan. Dalam penelitian ini pun, siswa menggunakan bilanganbilangan yang tidak sesuai dalam menyusun persamaan linear dua variabel. Selain penggunaan bilangan, siswa juga mengguakan operasi yang tidak sesuai untuk menyusun persamaan linear dua variabel. Hal ini sejalan dengan penelitian Sajadi et al. (2013) yang menyatakan bahwa beberapa siswa tidak tahu operasi apa (penjumlahan atau pengurangan) yang perlu digunakan untuk menyelesaikan masalah.

Kesulitan dalam tahap merencanakan penyelesaian masalah menyebabkan siswa mengalami kesulitan dalam tahap melaksanakan rencana penyelesaian. Untuk menyelesaikan suatu soal cerita, siswa perlu mengidentifikasi informasi yang hilang, menentukan suatu rencana dan menampilkan kalkulasi untuk menemukan informasi yang hilang (Powell, 2012). Oleh karena siswa tidak dapat merencanakan penyelesaian dengan baik, seperti membuat representasi atau model matematika, siswa juga tidak mampu menampilkan langkah penyelesaian yang sesuai pula. Hal ini didukung oleh penelitian Jupri \& Drijvers (2016) yang menyatakan bahwa siswa yang mengalami kesulitan dalam menyusun model matematika akan mengalami kesulitan dalam menampilkan langkah penyelesaian. Akibatnya siswa hanya mengoperasikan secara acak bilangan-bilangan yang tersaji dalam soal.

\section{SIMPULAN}

Berdasarkan hasil penelitian dan pembahasan, kesulitan utama yang dialami siswa SMP Negeri 1 Karangrejo terjadi dalam tahap merencanakan penyelesaian masalah. Kesulitan yang dialami siswa dalam tahap merencanakan penyelesaian masalah adalah kesulitan dalam mengubah informasi relevan ke dalam variabel dan kesulitan dalam menyusun persamaan linear dua variabel yang menunjukkan hubungan antar informasi relevan. Penyebab kesulitan yang dialami siswa adalah siswa mengalami kesulitan dalam memahami masalah, keterampilan representasi siswa yang masih kurang, dan siswa mengalami kesalahan dalam mengidentifikasi informasi relevan. Siswa mengalami kesulitan dalam memahami masalah dikarenakan susunan kata yang digunakan kalimat dalam soal cerita yang rumit atau masih asing bagi siswa. Kesulitan dalam tahap merencanakan penyelesaian masalah juga menyebabkan siswa mengalami kesulitan dalam tahap melaksanakan rencana penyelesaian. Oleh karena siswa tidak dapat merencanakan penyelesaian dengan baik, siswa juga tidak mampu menampilkan langkah penyelesaian yang sesuai pula.

Hasil penelitian belum sepenuhnya menunjukkan kesulitan siswa dalam penyelesaian sistem persamaan linear dua variabel, sehingga perlu diadakan penelitian yang dapat mengidentifikasi lebih dalam mengenai kesulitan siswa tersebut. Walaupun siswa sudah mempelajari materi sistem persamaan linear dua variabel, siswa masih belum bisa mengubah informasi relevan dalam bentuk kalimat biasa ke dalam representasi matematika. Untuk pembelajaran materi sistem persamaan linear dua variabel selanjutnya, guru hendaknya menekankan pembelajaran yang dapat membantu siswa dalam memformulasikan persamaan dari informasi relevan dalam soal cerita matematika.

\section{DAFTAR RUJUKAN}

Ahmad, A., Tarmizi, R. A., \& Nawawi, M. (2010). Visual Representations in Mathematical Word Problem Solving among Form Four Students in Malacca. Procedia - Social and Behavioral Sciences, 8(February), 356-361. https://doi.org/10.1016/j.sbspro.2010.12.050

Anton, H., \& Rorres, C. (2005). Elementary Linear Algebra (Ninth). John Wiley \& Sons, Inc.

Boonen, A. J. H., de Koning, B. B., Jolles, J., \& van der Schoot, M. (2016). Word Problem Solving in Contemporary Math Education: A Plea for Reading Comprehension Skills Training. Frontiers in Psychology, 7(February), 1-10. https://doi.org/10.3389/fpsyg.2016.00191 
Daroczy, G., Wolska, M., Meurers, W. D., \& Nuerk, H. C. (2015). Word problems: A Review of Linguistic and Numerical Factors Contributing to their Difficulty. Frontiers in Psychology, 6(1), 1-13. https://doi.org/10.3389/fpsyg.2015.00348 Fatmanissa, N., \& Kusnandi. (2017). The Linguistic Challenges of Mathematics Word Problems: A Research and Literature Review. Malaysian Journal of Learning and Instruction (MJLI), Special Issue on Graduate Students Research on Education, 73-92.

Jupri, A., \& Drijvers, P. (2016). Student Difficulties in Mathematizing Word Problems in Algebra. Eurasia Journal of Mathematics, Science and Technology Education, 12(9), 2481-2502. https://doi.org/10.12973/eurasia.2016.1299a

Kingsdorf, S., \& Krawec, J. (2014). Error Analysis of Mathematical Word Problem Solving Across Students with and without Learning Disabilities. Learning Disabilities Research \& Practice, 29(2), 66-74. https://doi.org/10.1111/ldrp.12029

Larson, R., \& Hostetler, R. (2008). Intermediate Algebra (Fourth). New York: Houghton Mifflin Company.

Powell, S. R. (2012). Solving Word Problems using Schemas: A Review of The Literature. Learn Disabil Res Pract., 26(2), 94108. https://doi.org/10.1111/j.1540-5826.2011.00329.x.Solving

Sahendra, A., Budiarto, M. T., \& Fuad, Y. (2018). Students' Representation in Mathematical Word Problem-Solving: Exploring Students' Self-efficacy Students' Representation in Mathematical Word Problem- Solving: Exploring Students' SelfEfficacy. Journal of Physics: Conference Series 947012059.

Sajadi, M., Amiripour, P., \& Rostamy-malkhalifeh, M. (2013). The Examining Mathematical Word Problems Solving Ability under Efficient Representation Aspect. Mathematics Education Trends and Research, 2013(2013), 1-11. https://doi.org/10.5899/2013/metr-00007

Sepeng, P., \& Sigola, S. (2013). Making Sense of Errors Made by Learners in Mathematical Word Problem Solving. Mediterranean Journal of Social Sciences, 4(13), 325-333. https://doi.org/10.5901/mjss.2013.v4n13p325

Verschaffel, L., Greer, B., Mukhopadhyay, S., \& Van Dooren, W. (2009). Words and Worlds. In Words and Worlds: Modelling Verbal Descriptions of Situations (pp. 3-19).

Yuan, S. (2013). Incorporating Pólya's Problem Solving Method in Remedial Math. Journal of Humanistic Mathematics, 3(1), 96-107. https://doi.org/10.5642/jhummath.201301.08 